\title{
Visualisasi Kualitas Penyebaran Informasi Gempa Bumi di Indonesia Menggunakan Twitter
}

\author{
Mira Chandra Kirana ${ }^{1 *}$, Nanda Putra Perkasa ${ }^{2 * * *}$, Muhammad Zainuddin Lubis ${ }^{3 * * *}$ Maidel Fani ${ }^{4 * *}$ \\ * Teknik Informatika, Politeknik Negeri Batam \\ ** Teknik Multimedia Jaringan, Politeknik Negeri Batam \\ ***Teknik Geomatika, Politeknik Negeri Batam \\ $\underline{\text { mira@polibatam.ac.id }}{ }^{1}$, nanda.putra.perkasa@gmail.com ${ }^{2}$, zainuddinlubis@polibatam.ac.id $^{3}$, maidelfani@polibatam.ac.id ${ }^{4}$
}

\begin{tabular}{l} 
Article Info \\
\hline Article history: \\
Received 14-04-2019 \\
Revised 08-05-2019 \\
Accepted 10-05-2019 \\
\hline
\end{tabular}

Keyword:

Gempa Bumi,

Visualisasi,

Penyebaran Informasi,

Kualitas Informasi

\begin{abstract}
Indonesia merupakan salah satu negara dengan tingkat bencana alam yang cukup tinggi, seperti gempa bumi, sehingga penyebaran informasi mengenai peringatan dini sangat penting. Media sosial Twitter menjadi salah satu tempat penyebaran informasi mengenai peringatan dini bencana alam gempa bumi di Indonesia melalui akun BMKG. Namu belum diketahui kualitas penyebaran informasi dari media sosial Twitter tersebut, oleh karena itu dibuatlah visualisasi untuk menganalisis kualitas penyebaran informasi dengan media sosial Twitter. Penelitian ini dilakukan dengan tiga tahap, yaitu retrieving, preprocessing kemudian visualisasi. Proses retrieving digunakan untuk mengambil data Tweet akun BMKG di Twitter. Tahap preprocessing berfungsi untuk mendapatkan hasil analisis kualitas informasi gempa bumi. Setelah itu hasil analisis data ketepatan waktu, relevansi, kelengkapan data beserta keakuratan data dibuat kesimpulan yang menyatakan kualitas informasi penyebaran gempa bumi, lalu hasilnya di tampilkan dalam bentuk visualisasi grafik.
\end{abstract}

Copyright (C) 2019 Journal of Applied Informatics and Computing. All rights reserved

\section{Pendahuluan}

Indonesia merupakan negara yang memiliki letak geografis strategis. Indonesia terdiri dari beberapa pulau besar dan ribuan pulau-pulau kecil, dimana masih terdapat rangkaian gunung api yang masih aktif. Hal tersebut dapat memicu terjadinya banyak bencana alam yang tidak hanya berasal dari gunung api yang masih aktif, bisa juga berasal dari pergeseran lempeng bumi yang terjadi secara alami. Keadaan alam yang selalu berubah juga dapat memicu terjadinya banyak bencana alam yang merupakan akibat dari berbagai faktor. Dikarenakan banyaknya bencana alam yang terjadi di Indonesia, sehingga Indonesia termasuk dalam Cincin Api Pasifik. Cincin Api Pasifik adalah daerah yang sering mengalami gempa bumi dan letusan gunung berapi yang mengelilingi cekungan Samudra Pasifik [1].

Di Indonesia terdapat sebuah lembaga yang melaksanakan tugas pemerintahan dan bertanggung jawab dibidang meteorologi, klimatologi dan geofisika (BMKG). Peringatan dini bencana alam merupakan peringatan untuk menginformasikan kepada masyarakat tentang bencana alam yang akan terjadi tanpa menunda dan bersamaan melalui beberapa saluran [2].

Seiring berkembangnya zaman, penyebaran informasi melalui teknologi saat ini sudah semakin mudah dan cepat. Salah satu cara untuk melakukan penyebaran informasi yang cepat yaitu dengan melalui media sosial. Media sosial yang masih cukup banyak pengguna khususnya di Indonesia adalah Twitter. Media sosial Twitter dapat membantu pihak BMKG dalam menyebarkan informasi peringatan dini bencana alam karena banyaknya jumlah pengguna Twitter di Indonesia.

Text Mining pada Twitter adalah sebuah proses yang dapat menganalisis data berupa teks dari tingkat keakuratan serta menghitung potensi-potensi yang muncul dari data tersebut secara otomatis. Dalam hal ini data tersebut adalah Tweet akun BMKG di Twitter. Dengan data yang telah diolah tersebut, hasil yang didapatkan adalah pengelompokkan data untuk menganalisis kualitas informasi dari Tweet informasi gempa bumi BMKG di media sosial Twitter. Penelitian ini menggunakan pendekatan Text Mining dengan bantuan Natural Languange Processing atau yang biasa dikenal dengan NLP. NLP digunakan untuk menyederhanakan data 
Tweet agar mudah di analisis sebagai data yang relevan dan tidak relevan dalam proses text mining.

Selain menggunakan NLP, penelitian ini juga menggunakan algoritma pencocokan string brute force yang berfungsi memecahkan suatu masalah yang biasanya di dasarkan pada pernyataan masalah definisi konsep yang dilibatkan. Algoritma brute force memecahkan masalah dengan sangat sederhana, langsung dan dengan cara yang jelas. Di dalam penelitian ini algoritma brute force berperan dalam menganalisis data teks Tweet tingkat relevansinya.

Penelitian ini menggunakan 2 jenis visualisasi di dalam tahap penyajian data, yaitu visualisasi grafik dan peta persebaran [3]. Visualisasi grafik menampilkan kualitas penyebaran informasi gempa bumi yang dilakukan pihak BMKG di media sosial Twitter. Sedangkan visualisasi peta persebaran menunjukkan lokasi pengguna Twitter yang melakukan retweet terhadap tweet $\mathrm{BMKG}$ mengenai gempa bumi terjadi selama 6 bulan, dari bulan Januari hinga bulan Juni di tahun 2018.

Visualisasi di dalam penelitian ini, menunjukkan kualitas informasi atau tingkat efektivitas penyebaran informasi peringatan dini bencana alam melalui akun BMKG di media sosial Twitter. Data di dapatkan dari tahap pengumpulan data tweet akun BMKG di media sosial Twitter, yang telah diolah dan dianalisis. Dengan visualisasi grafik dan peta persebaran, hasil yang ditampilkan menjadi lebih jelas dan mudah di pahami.

\section{Tinjauan Pustaka}

\section{A. Twitter}

Twitter adalah sebuah situs web yang dimiliki dan dioperasikan oleh Twitter Inc., yang menawarkan jaringan sosial berupa mikroblog sehingga memungkinkan penggunanya untuk mengirim dan membaca pesan tweet. Twitter merupakan tempat akses utama data yang menjadi topik dari penelitian ini. Dan data dari media sosial Twitter yang dikumpulkan dan diolah adalah:

1. Tweet

Tweet adalah sesuatu yang ditulis user di media sosial Twitter. Dalam penelitian ini Tweet yang dikumpulkan untuk di analisis berasal dari akun BMKG yang merupakan pihak yang bertanggung jawab dalam informasi gempa bumi di Indonesia.

2. Retweet

Retweet merupakan pengulangan dari Tweet user yang kemudian di tulis ulang dan bisa ditambahkan sisipan kata. Retweet disini menunjukkan jumlah responden dari Tweet $\mathrm{BMKG}$.

\section{B. Python}

Python merupakan salah satu bahasa pemrograman interpretative, intraktif, berbasis objek dan bisa dijalankan di semua platform [4]
Di dalam penelitian ini, Python digunakan sebagai bahasa pemograman untuk membuat skrip yang berfungsi sebagai retrieval data Tweet akun BMKG di Twitter, Text Mining data Tweet relevan dan tidak relevan dan visualisasi. Berikut adalah library-library yang digunakan di dalam penelitian ini:

1. Tweepy

Tweepy adalah library Python yang bertugas untuk mengakses API milik Twitter. Tweepy merupakan library Python yang dapat mengakses API milik Twitter sehingga dapat membuat bot retrieving data dari Twitter dengan skrip Python. Tweepy digunakan untuk menjembatani bahasa pemograman Python dengan Twitter di penelitian ini. Dengan menggunakan library Tweepy, data Tweet dari akun BMKG di Twitter dapat di kumpulkan dan di akses untuk bahan penelitian.

2. PyMySQL

Library PyMySQL digunakan untuk menghubungkan basis data server dengan bahasa pemograman Python. Dengan adanya library PyMySQL, dapat memudahkan untuk melakukan pengolahan data yang ada di basis data MySQL.

3. Unidecode

Library Unidecode bekerja sama pada proses Text Mining di dalam bahasa pemograman Python. Library Unidecode berfungsi pada tahap Case Folding di dalam Text Mining, yaitu membuat semua huruf menjadi huruf kecil (lower case).

4. NLTK (Natural Languange Tool Kit)

Library NTLK di dalam penelitian ini digunakan pada tahap Tokenizing, yaitu berfungsi untuk memisahkan kata-kata pada setiap kalimat yang akan diolah.

5. Sastrawi

Library Sastrawi merupakan library yang mempunyai peran penting di dalam proses Text Mining, terutama di dalam pengolahan teks Bahasa Indonesia. Library Sastrawi di dalam penelitian ini digunakan pada tahap Stopword dan Stemming, dimana tahap-tahap tersebut berfungsi untuk menghapus kata-kata yang tidak berhubungan dan menyederhanakan kata menjadi kata dasar.

\section{Text Mining}

Text mining adalah penambangan yang dilakukan oleh komputer untuk menemukan informasi dan pengetahuan yang berguna yang tidak diketahui sebelumnya sehingga menemukan sesuatu yang baru yang berasal dari sumber yang berbeda-beda [5]. Text mining merupakan teknik yang digunakan untuk menangani masalah classification, clustering, information extraction dan information retrieval. Text Mining di dalam penelitian ini berfungsi untuk mengolah dokumen teks yang telah dikumpulkan di dalam basis data 
yang berupa Tweet untuk dapat diolah ke tahapan selanjutnya. Text Mining memiliki 2 tahapan, yaitu:

\section{Text Pre-processing}

Text Preprocessing merupakan tahapan awal terhadap teks untuk mempersiapkan teks menjadi data yang dapat diolah lebih lanjut. Berikut penjelasan proses tahapan Text Preprocessing:

\section{- Case Folding}

Case Folding berfungsi untuk merubah semua huruf pada dokumen teks menjadi huruf kecil dan menghapus delimiter yang merupakan karakter selain huruf. Ilustrasi case folding yaitu mengubah semua karakter menjadi huruf kecil di tampilkan pada gambar 1 .

\begin{tabular}{|c|c|}
\hline $\begin{array}{l}\text { Ibukota Negara } \\
\text { Indonesia merupakan } \\
\text { Jakarta, sedangkan } \\
\text { Bali adalah kota di } \\
\text { Indonesia yang } \\
\text { terpopuler di Dunia. }\end{array}$ & $\begin{array}{l}\text { ibukota negara } \\
\text { indonesia } \\
\text { merupakan jakarta } \\
\text { sedangkan bali } \\
\text { adalah kota di } \\
\text { indonesia yang } \\
\text { terpopuler di dunia }\end{array}$ \\
\hline
\end{tabular}

\section{- Tokenizing}

Tokenizing adalah tahap pemotongan string berdasarkan pada tiap kata yang menyusunnya. Menguraikan kalimat menjadi kata per-kata di ilustrasikan pada gambar 2 .

\begin{tabular}{|c|c|}
\hline $\begin{array}{lr}\text { ibukota } & \text { negara } \\
\text { indonesia } & \\
\text { merupakan } & \text { jakarta } \\
\text { sedangkan } & \text { bali } \\
\text { adalah kota di } \\
\text { indonesia yang } \\
\text { terpopuler di dunia }\end{array}$ & 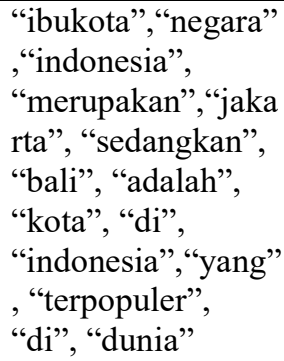 \\
\hline
\end{tabular}

\section{Text Transformation}

Text Transformation merupakan tahapan yang dipergunakan untuk menyederhanakan kata menjadi kata dasar, serta menghilangkan kata-kata yang tidak berhubungan seperti kata sambung. Dalam hal ini diperlukan library yang memiliki bahasa yang sesuai dengan bahasa dokumen teks yang akan diolah. Berikut tahapan-tahapan Text Transformation:

\section{- Stopword Removal / Filtering}

Tahap Stopword Removal berfungsi untuk menghilangkan kata-kata yang tidak penting atau katakata yang tidak berhubungan. Ilustrasi dari tahapan stopword yaitu menghilangkan kata-kata tidak penting ditampilkan pada gambar 3 .

\begin{tabular}{|c|c|}
\hline 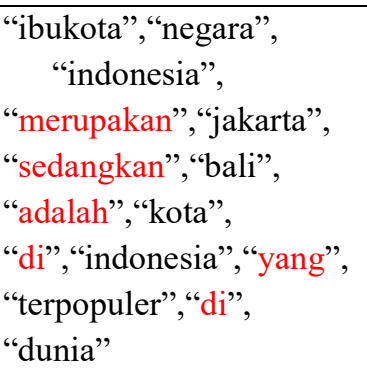 & $\begin{array}{l}\text { "ibukota", "negara", } \\
\text { "indonesia", } \\
\text { "jakarta", "bali", } \\
\text { "kota", } \\
\text { “indonesia", } \\
\text { "terpopuler", } \\
\text { "dunia" }\end{array}$ \\
\hline
\end{tabular}

- Stemming

Stemming merupakan tahap untuk menyederhanakan kata. Tahap Stemming berfungsi untuk mencari kata dasar pada dokumen teks yang akan diolah. Ilustrasi stemming yaitu menyederhanakan kata menjadi kata dasar ditampilkan pada gambar 4 .

\begin{tabular}{|c|c|}
\hline $\begin{array}{l}\text { "ibukota", "negara", } \\
\text { "indonesia", } \\
\text { "jakarta", "bali", } \\
\text { "kota", "indonesia", } \\
\text { "terpopuler", } \\
\text { "dunia" }\end{array}$ & $\begin{array}{l}\text { "ibukota", "negara", } \\
\text { "indonesia", } \\
\text { "jakarta", "bali", } \\
\text { "kota", "indonesia", } \\
\text { "terpopuler", } \\
\text { "dunia", }\end{array}$ \\
\hline
\end{tabular}

\section{Algoritma Pencocokan String (brute force)}

Algoritma brute force adalah sebuah pendekatan yang lempang (straight forward) untuk memecahkan suatu masalah, biasanya didasarkan pada pernyataan masalah (problem statement) definisi konsep yang dilibatkan. Algoritma brute force memecahkan masalah dengan sangat sederhana, langsung dan dengan cara yang jelas [6]

Cara kerja Algoritma brute force:

1. Mula-mula string dicocokkan pada awal teks.

2. Dengan bergerak dari kiri ke kanan, dibandingan setiap karakter di dalam string dengan karakter yang bersesuaian di dalam teks, jika sesuai dibandingkan tersebut mengeluarkan hasil.

3. Jika string belum ditemukan kecocokan dari teks belum habis, maka geser string satu karakter ke kananda dan berulang ke langkah 2 . 
Contoh dari Algoritma brute force:

Teks : nobody noticed him

Pattern : not

nobody noticed him

step $=0$ not

step $=1$ not

step $=2$ not

step $=3$ not

step $=4$ not

step $=5$ not

step $=6$ not

step $=7 \quad$ not

Pada langkah ke-7, pencarian telah berhenti karna sudah menemukan kata yang cocok dengan pattern. Algoritma brute force di dalam penelitian ini berfungsi untuk mengklasifikasikan data Tweet yang relevan dan yang tidak relevan untuk menganalisis tingkat efektivitas dari penyebaran informasi bencana alam gempa bumi pada akun BMKG di media sosial Twitter.

\section{E. Kualitas Informasi}

Nilai informasi ditentukan oleh banyak hal, diantaranya adalah kualitas informasi karena secara tidak langsung nilai informasi akan diperoleh. Kualitas informasi adalah "tingkat dimana informasi memiliki karakteristik isi, bentuk, dan waktu yang memberikannya nilai buat para pemakai akhir tertentu [7]. McLeoad mengemukakan bahwa suatu informasi yang berkualitas harus memiliki ciri-ciri sebagai berikut [8]:

1) Akurat

Informasi harus bebas dari kesalahan-kesalahan dan tidak menyesatkan. Akurat juga berarti informasi harus jelas mencerminkan maksudnya. Informasi harus akurat karena dari sumber informasi sampai ke penerima informasi kemungkinan banyak terjadi gangguan (noise) yang dapat mengubah informasi tersebut.

Di dalam penelitian ini, untuk tingkat akurasi dari data Tweet sudah terpenuhi, dikarenakan data di ambil langsung dari Tweet pihak BMKG di media sosial Twittter dan merupakan badan resmi penyebaran informasi bencana alam di Indonesia yang memiliki metode sendiri untuk meneliti bencana alam khususnya gempa bumi yang terjadi di Indonesia.

\section{2) Tepat Waktu}

Informasi yang datang pada si penerima tidak boleh terlambat. Informasi yang sudah usang tidak akan mempunyai nilai lagi karna informasi merupakan landasan dalam pengambilan keputusan. Informasi tepat waktu harus tersedia atau ada pada saat informasi tersebut diperlukan, tidak besok atau beberapa jam lagi, sehingga bisa disimpulkan bahwa informasi bencana alam khususnya gempa bumi yang tepat waktu tidak lebih dari satu jam. Di dalam penelitian ini, untuk menentukan Tweet informasi gempa bumi yang tepat waktu yaitu waktu terjadinya gempa yang sudah ditambahkan satu jam lalu dibandingkan dengan waktu ketika Tweet dibuat. Apabila waktu Tweet lebih kecil dibandingkan waktu terjadinya gempa yang sudah ditambahkan satu jam, maka Tweet tersebut merupakan informasi yang tepat waktu.

\section{3) Relevan}

Relevan artinya, Informasi yang diberikan harus sesuai dengan yang dibutuhkan. Relevansi informasi untuk orang satu dengan orang yang lain berbeda. Relevan di dalam penelitian ini adalah, apabila informasi Tweet mengandung kata gempa bumi di dalamnya.

\section{4) Lengkap}

Lengkap ialah tidak boleh ada bagian informasi yang penting atau esensial bagi pengambil keputusan atau pelaksanaan tugas yang hilang, karena menghasilkan keputusan yang salah nantinya. Di dalam penelitian ini, informasi Tweet yang lengkap mengandung informasi gempa bumi yang berisikan data-data penting di dalamnya.

Dalam penelitian ini, menggunakan tabel standar efektivitas untuk menentukan tingkat kualitas informasi khususnya efektivitas dari hasil pengolahan data penyebaran informasi gempa bumi akun BMKG di Twitter dalam bentuk persentase.

TABEL I.

TABEL STANDAR EFEKTIFITAS

\begin{tabular}{|c|c|}
\hline Rasio Efektivitas & Tingkat Capaian \\
\hline$<40 \%$ & Sangat Tidak Efektif \\
\hline $40 \%-59.99 \%$ & Tidak Efektif \\
\hline $60 \%-79.99 \%$ & Cukup Efektif \\
\hline$>80 \%$ & Sangat Efektif \\
\hline
\end{tabular}

\section{F. Visualisasi}

Visualisasi adalah rekayasa dalam pembuatan gambar, diagram atau animasi bahkan pemetaan untuk penampilan suatu informasi.

1) Metode penggunaan komputer untuk mentransformasi simbol menjadi geomterik.

2) Memungkinkan peneliti mengamati simulasi dan komputasi.

3) Memberikan cara untuk melihat yang tidak terlihat

4) Memperkaya proses penemuan ilmiah dan mengembangkan pemahaman yang lebih dalam dan tak diduga 
5) Dalam berbagai bidang telah merevolusikan cara ilmuwan meneliti sains.

Penelitian ini menggunakan 2 jenis visualisasi, yaitu visualisasi grafik dan peta persebaran.

\section{Metode Penelitian}

Penelitian yang dilakukan ini dibagi menjadi 3 tahap, tahapan yang pertama yaitu tahap pengumpulan data. Setelah data dikumpulkan tahapan selanjutnya yaitu pengolahan data dimana data diolah menjadi data yang lebih berkualitas. Setelah itu tahap penyajian data yang berisikan visualisasi dari data olahan.

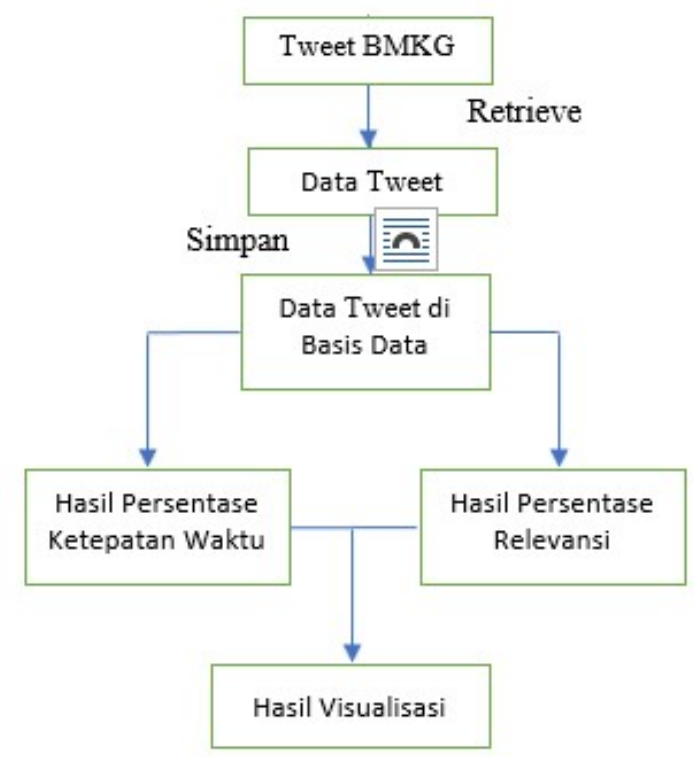

Gambar 5. Tahapan Proses Penelitian

Gambar 5 menunjukkan tahapan proses di dalam penelitian ini secara keseluruhan. Dimana pada tahapan awal yang dilakukan adalah melakukan retrieve dari Tweet akun BMKG di Twitter dan langsung disimpan ke Basis Data. Data Tweet yang ada di Basis Data diolah dan dianalisis hingga hasil yang di dapatkan adalah persentase ketepatan waktu. Dan data Tweet yang ada di Basis Data dengan melakukan pengolahan data teks dan analisis sehingga hasil yang di dapatkan adalah persentase relevansi data Tweet. Dari hasil yang telah di dapatkan dibuat visualisasi agar hasilnya lebih mudah dimengerti.

\section{A. Teknik Pengumpulan Data}

Teknik pengumpulan data yang digunakan dalam penelitian ini yaitu observasi. Langkah-langkah yang dilakukan dalam observasi sebagi berikut:

1. Melakukan retrieving data Tweet dari akun BMKG di Twitter dengan menggunakan skrip Python dan bantuan
Library Tweepy.

Variabel-variabel yang dipelajari dalam retrieving data Tweet yaitu:

- ID

Nomor id dari Tweet BMKG di Twitter

- $\quad$ Text Tweet

Isi dari teks Tweet akun BMKG di media sosial Twitter. Digunakan untuk mengolah dan mendapatkan hasil analisis data.

- Retweet_count Jumlah retweet dari Tweet BMKG di Twitter

- Favourite count Jumlah favourite dari Tweet BMKG di Twitter

- Date_time

Merupakan tanggal dari Tweet dibuat. Digunakan untuk mengetahui tanggal dan waktu ketika di publikasi.

2. Menyimpan data-data Tweet yang telah di dapatkan lalu disimpan ke dalam basis data.

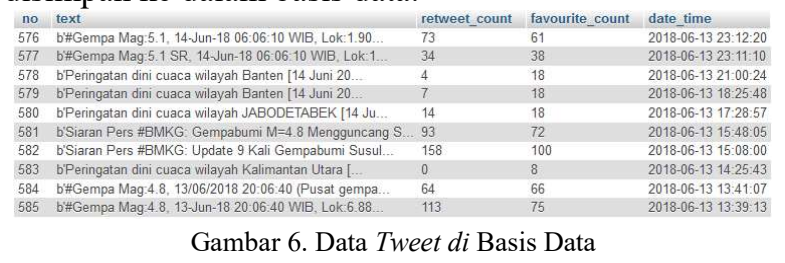

Gambar 6 menunjukkan contoh data yang di dapatkan dalam proses pengambilan data Tweet BMKG di Twitter. No pada gambar merupakan nomor urutan pengumpulan data, text merupakan isi dari Tweet, retweet_count merupakan jumlah Retweet, favourite_count merupakan jumlah Favourite dan date_time merupakan waktu dari tweet tersebut di buat

B. Teknik Pengolahan dan Analisis Data

Tahap-tahap yang dilakukan untuk pengolahan data dan analisis data adalah sebagai berikut:

1. Mengolah data Tweet yang tersimpan di dalam basis data dengan skrip pengolahan data dan library penghubung.

2. Melakukan analisis pengolahan data untuk mengetahui ketepatan waktu dari informasi Tweet gempa bumi. Pengolahan data yang dilakukan yaitu membandingkan waktu terjadinya gempa dengan waktu Tweet dibuat. Dikarenakan kriteria informasi yang tepat waktu tidak lebih dari beberapa jam, sehingga apabila waktu Tweet dibuat, tidak lebih satu jam dari waktu terjadinya gempa, maka Tweet tersebut termasuk informasi yang tepat waktu. 


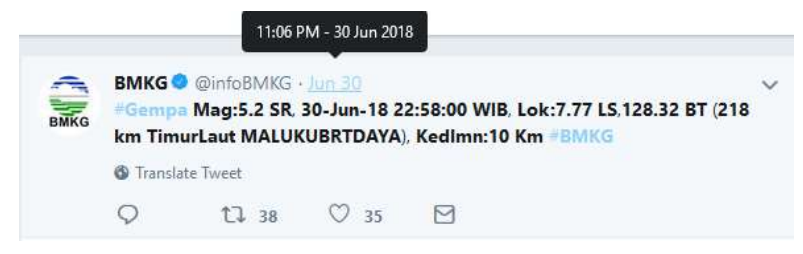

Gambar 5. Tweet Informasi Gempa Tepat Waktu

Gambar 7 menunjukkan contoh Tweet informasi gempa bumi yang dilakukan secara tepat waktu, sehingga $u$ ser yang mendapatkan informasi bisa dengan segera melakukan tindakan mitigasi bencana gempa bumi.

3. Text Mining digunakan untuk menyederhanakan teks Tweet agar mudah dianalisis menggunakan Natural Languange Processing. Proses text mining secara umum terbagi 2, yaitu:

- $\quad$ Text Processing

Tindakan yang dilakukan pada tahap ini adalah toLowerCase, yaitu mengubah semua karakter huruf menjadi huruf kecil dan Tokenizing yang berfungsi sebagai penguraian deskripsi yang semula berupa kalimat menjadi kata-kata lalu menghilangkan delimiter-delimiter seperti tanda titik (.), koma (,), spasi dan karakter angka.

- Featured Selection

Tindakan yang dilakukan adalah stopword removal yaitu menghilangkan kata-kata yang tidak berhubungan seperti kata sambung dan stemming yaitu melakukan penyederhanaan kata menjadi kata dasar terhadap isi teks Tweet yang dianalisis.

4. Menggunakan algoritma pencocokan string (brute force) untuk menganalisis kelengkapan dan relevansi dari data teks Tweet. Setelah data teks Tweet melewati tahapan text mining, lalu dilakukan pencocokan dengan kriteria data teks yang lengkap dan relevan untuk menganalisis tingkap kelengkapan dan relevansi dari isi teks Tweet.

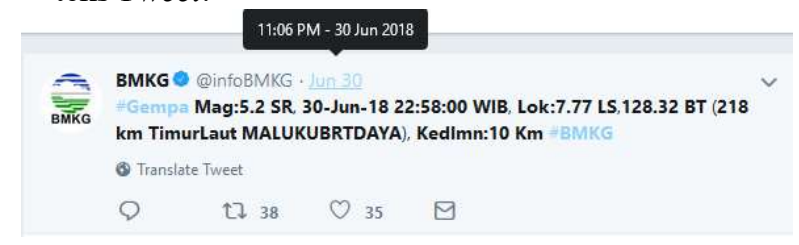

Gambar 6. Tweet Informasi Gempa yang Baik

Gambar 8 menunjukkan contoh Tweet relevan terhadap Tweet informasi gempa bumi dan mengandung informasi yang lengkap. Dapat dilihat pada gambar, Tweet masih mengandung informasi penting mengenai informasi gempa bumi, seperti:

- Menampilkan kata "gempa" di dalam isi teks Tweet yang menunjukkan informasi tersebut termasuk dalam kategori bencana alam gempa bumi. Data ini digunakan untuk menentukan relevansi Tweet informasi tersebut dengan informasi gempa bumi.

- Menampilkan informasi kekuatan gempa, yaitu "Mag:5.2"

- Menampilkan waktu kejadian dari gempa yang akan terjadi

- Menampilkan lokasi titik gempa dalam bentuk satuan lintang dan bujur

- Menampilkan informasi daerah terjadinya gempa

- Menampilkan kedalaman gempa

5. Visualisasi data yang telah dikumpulkan dari hasil analisis ke dalam bentuk grafik dan peta persebaran.

6. Hasil visualisasi grafik menampilkan hasil analisis relevansi, ketepatan waktu dan kelengkapan data dalam kurun waktu 6 bulan, dari bulan Januari hingga Juni tahun 2018.

7. Hasil visualisasi peta persebaran yang di tampilkan merupakan peta yang dibuat oleh pihak BMKG. Peta menampilkan titik-titik gempa yang terjadi dalam kurun waktu 6 bulan, dari bulan Januari hingga bulan Juni tahun 2018

8. Dari visualisasi grafik dan peta persebaran dapat disimpulkan kualitas penyebaran informasi dari Tweet akun BMKG di Twitter.

\section{Teknik Penyajian Data}

Penyajian data yang digunakan yaitu melakukan visualisasi data ke dalam bentuk grafik dan peta persebaran agar lebih mudah dipahami.

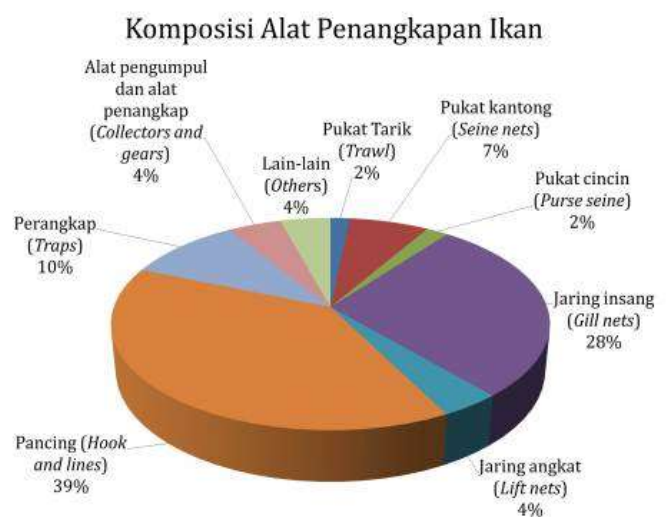

Gambar 9. Grafik Pie (Direktorat Jenderal Perikanan Tangkap, 2013)

Gambar 9 merupakan contoh penyajian data dari hasil visualisasi dalam bentuk grafik pie. Digunakan untuk memvisualisasikan kualitas informasi Tweet mengenai gempa bumi yang dilakukan oleh akun BMKG di media sosial Twitter. 


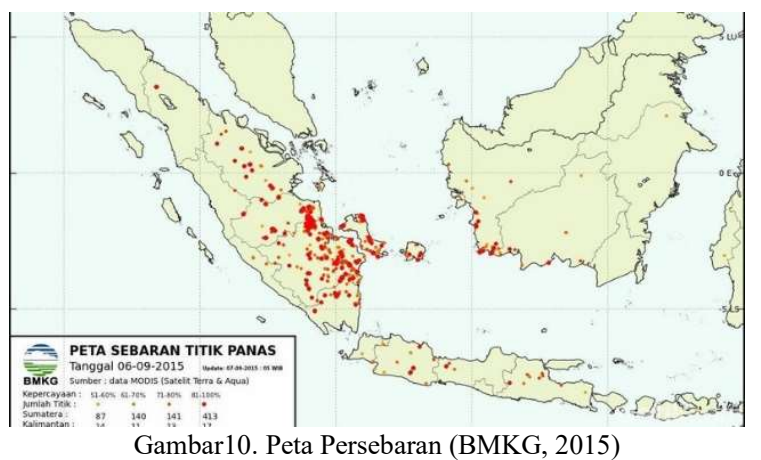

Gambar 10 merupakan contoh penyajian data visualisasi dalam bentuk peta persebaran. Digunakan untuk menampilkan titik informasi Tweet mengenai gempa bumi yang dilakukan oleh akun BMKG di media sosial Twitter.

\section{HASIL DAN PEMBAHASAN}

\section{A. Hasil Implementasi}

Hasil Implementasi dibagi menjadi 3 tahap yaitu retrieving data, preprocessing data dan visualisasi.

\section{1) Retrieving Data}

Pada tahap ini dilakukan retrieving data Tweet dan Reweet dari akun BMKG (@infoBMKG) di media sosial Twitter untuk mendapatkan data Tweet BMKG. Tahap Retrieving dilakukan dengan menjalankan skrip Retrieving_Timeline.py.

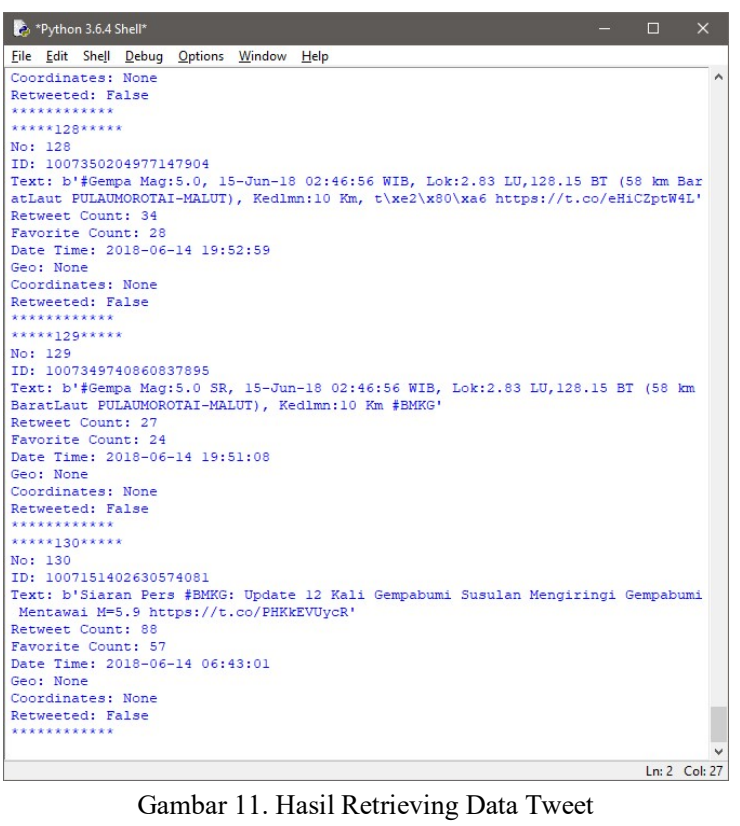

Gambar 11 menunjukkan hasil data dari proses retrieving data dari akun BMKG (@infoBMKG) di media sosial Twitter dan disimpan ke Basis Data.

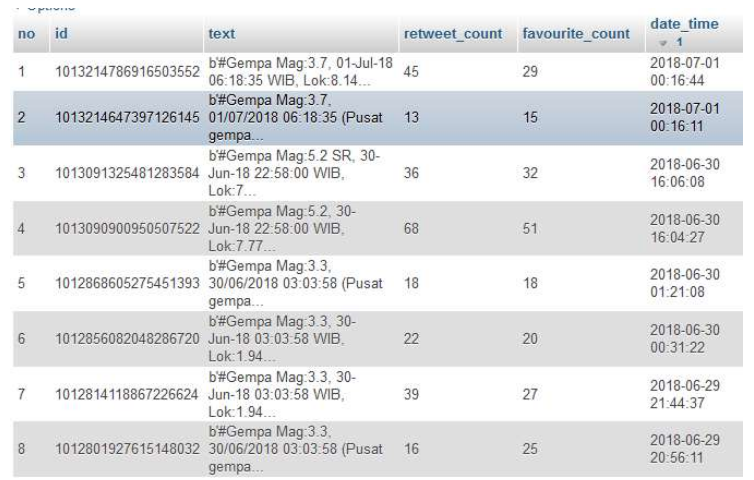

Gambar 12. Data Retrieving Tweet di Basis Data

Gambar 12 menunjukkan hasil data retrieving dari akun BMKG (@infoBMKG) di media sosial Twitter yang telah disimpan ke Basis Data.

\section{2) Prepossessing Data}

Pada tahap ini dilakukan Prepossesing data dari data yang telah dikumpulkan di basis data untuk mengolah dan mengimplementasikan metode Text Mining. Pada tahap ini, setelah data diolah dan disederhanakan agar mudah di pahami menggunakan NLP, data dicocokkan dengan pattern menggunakan algoritma pencocokkan string (brute force).

Pattern-pattern yang telah disediakan sebelumnya mengandung beberapa poin penting di dalam Tweet informasi gempa bumi, yaitu:

- Terdapat kata "gempa" di dalamnya. Menunjukkan bahwa informasi tersebut merupakan informasi mengenai gempa bumi. Data ini digunakan untuk menganalisis relevansi data Tweet dengan informasi gempa bumi.

- Besar kekuatan gempa.

- Waktu terjadinya gempa yang berfungsi sebagai memperingatkan user untuk dapat bersiap-siap menghadapi gempa bumi. Data ini diolah untuk dibandingkan dengan waktu Tweet sehingga didapatkan persentase ketepatan waktu.

- Titik koordinat terjadinya gempa

- Daerah di Indonesia yang tertimpa musibah gempa

- Kedalaman gempa yang terjadi

Poin-poin yang berisikan informasi penting gempa ini digunakan sebagai pattern pembanding untuk menentukan tingkat relevansi data dan kelengkapan informasi.

3) Visualisasi

Pada tahap ini dilakukan proses visualisasi dari data hasil Prepossesing ke dalam bentuk grafik. Implementasi perancangan input dan output data yang diperlukan yaitu:

- Menjalankan skrip "Retrieve_Timeline.py" untuk melakukan retrieving data dari akun BMKG di media sosial Twitter.

- Menjalankan skrip "Relevance \& Complete.py" untuk melakukan proses Prepossesing yang melakukan analisis 
terhadap data yang telah disimpan di Basis Data untuk mendapatkan hasil data tingkat relevansi dan kelengkapan data.

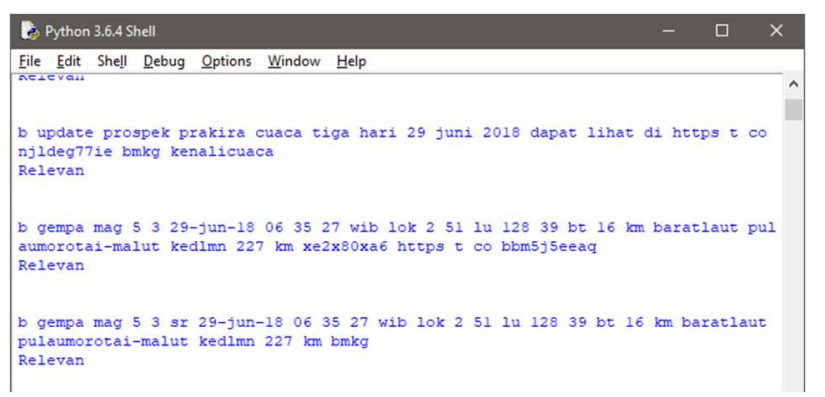

Gambar 13. Hasil Prepossessing Data Relevan

Gambar 13 menunjukkan hasil dari Prepossesing data yang relevan. Ketika teks yang sudah disederhanakan, dilakukan pengolahan data menggunakan algoritma pencocokan string (brute force) pada pattern yang sudah disediakan, teks Tweet tersebut mengandung poin informasi penting dari Tweet informasi gempa bumi, yaitu:

1) Terdapat kata "gempa".

Kata gempa menentukan relevan atau tidaknya data tersebut.

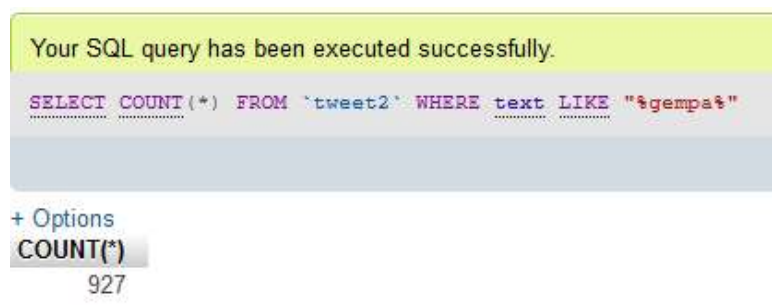

Gambar 14. Hasil Perhitungan Data Relevan

Gambar 14 menampilkan hasil dari perhitungan data yang relevan sebesar 927 dari 927 data, dan persentase yang didapatkan sebesar $100 \%$. Hasil persentase $100 \%$ didapatkan karena data yang diolah hanya data Tweet informasi gempa bumi BMKG di Twitter. Sedangkan untuk nilai kualitas informasi, dengan jumlah persentase data relevan dari kualitas informasi sebesar 25\%. Dan dari hasil persentase data relevan $100 \%$, maka di dapatkan hasil persentase sebesar $25 \%$.

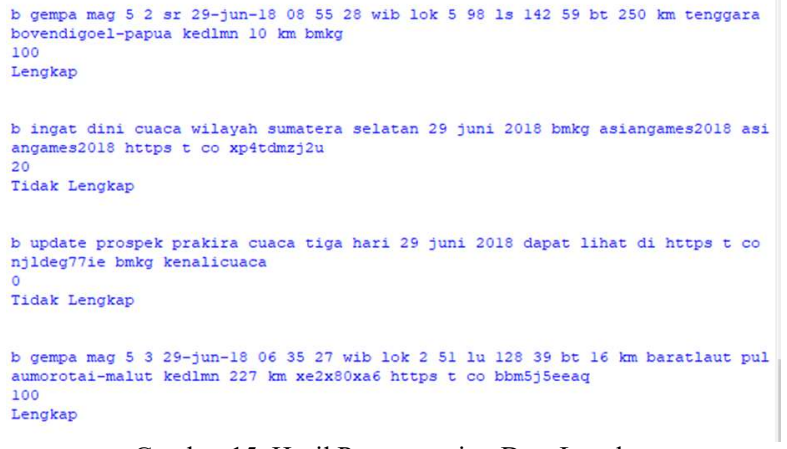

Gambar 15. Hasil Prepossessing Data Lengkap
Gambar 15 menunjukkan hasil dari Prepossesing data yang relevan. Ketika teks yang sudah disederhanakan, dilakukan pengolahan data menggunakan algoritma pencocokan string (brute force) pada pattern yang sudah disediakan, teks Tweet tersebut mengandung beberapa poin informasi penting dari Tweet informasi gempa bumi, yaitu:

2) Terdapat informasi kekuatan gempa (magnitude)

3) Terdapat informasi waktu terjadinya gempa bumi

4) Terdapat informasi titik koordinat gempa (epicenter) dengan satuan Lintang dan Bujur.

5) Terdapat informasi daerah terjadinya gempa di Indonesia

6) Terdapat informasi kedalaman gempa

Minimal terdapat 3 poin dari 5 poin penting untuk menentukan data tersebut merupakan data Lengkap. Apabila pada teks yang diolah mengandung 5 poin penting informasi gempa bumi, hasil yang didapatkan adalah data tersebut Lengkap dan apabila kurang dari 3 poin, hasilnya adalah data tersebut Tidak Lengkap.

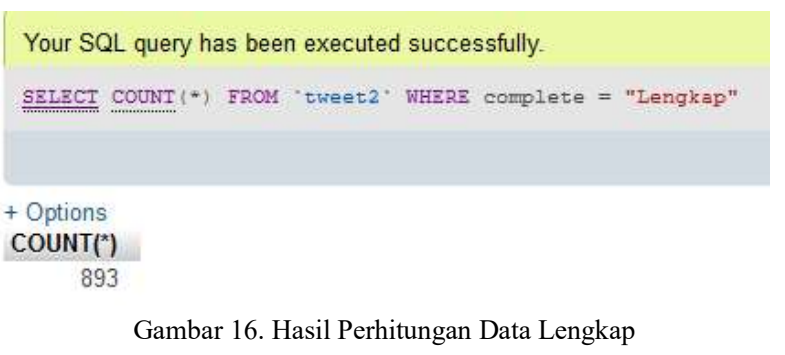

Gambar 16 menampilkan hasil perhitungan data yang lengkap sebesar 893 dari 927 data, dan persentase yang didapatkan sebesar $96.33 \%$.

Sedangkan untuk nilai kualitas informasi, dengan jumlah persentase data lengkap dari kualitas informasi sebesar $25 \%$. Dan dari hasil persentase data relevan 96.33\%, maka di dapatkan hasil persentase sebesar $24.08 \%$.

1) Menjalankan skrip "On_Time.py" untuk melakukan proses Prepossesing yang melakukan analisis terhadap data yang telah disimpan di Basis Data untuk mendapatkan hasil data ketepatan waktu.

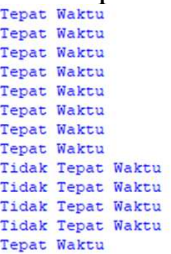

Tidak Tepat Waktu

Gambar 17. Hasil Prepossessing Data Tepat Waktu

Gambar 17 menunjukkan hasil dari Prepossesing data ketepatan waktu. Dengan melakukan perbandingan data yaitu waktu Tweet dibuat dan waktu terjadinya gempa dengan ditambahkan satu jam. 


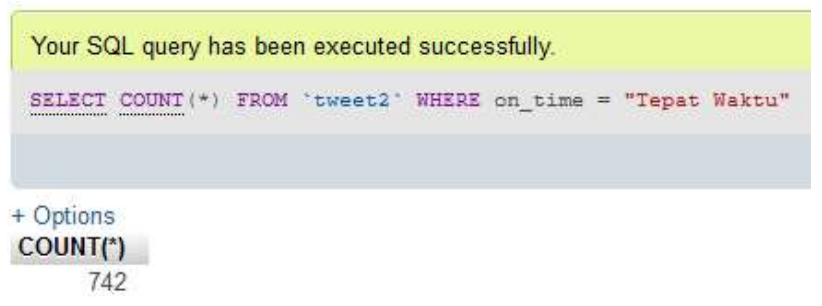

Gambar 18. Hasil Perhitungan Data Tepat Waktu

Gambar 18 menampilkan hasil dari perhitungan data yang tepat waktu sebesar 742 dari 927 data, dan persentase yang didapatkan sebesar $80.04 \%$.

Sedangkan untuk nilai kualitas informasi, dengan jumlah persentase data tepat waktu dari kualitas informasi sebesar $25 \%$. Dan dari hasil persentase data tepat waktu sebesar $80.04 \%$, maka di dapatkan hasil persentase sebesar $20.01 \%$.

\section{B. Pembahasan}

Berdasarkan implementasi dan pengujian yang di lakukan menghasilkan beberapa poin penting terhadap kualitas penyebaran informasi akun BMKG di media sosial Twitter, antara lain:

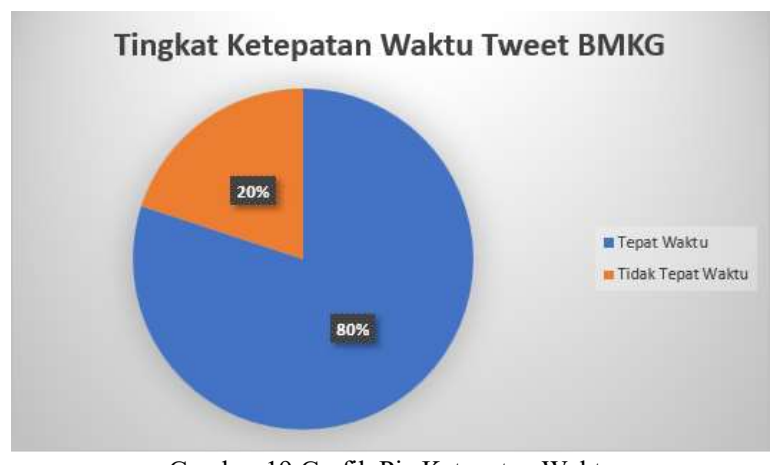

Gambar 19 Grafik Pie Ketepatan Waktu

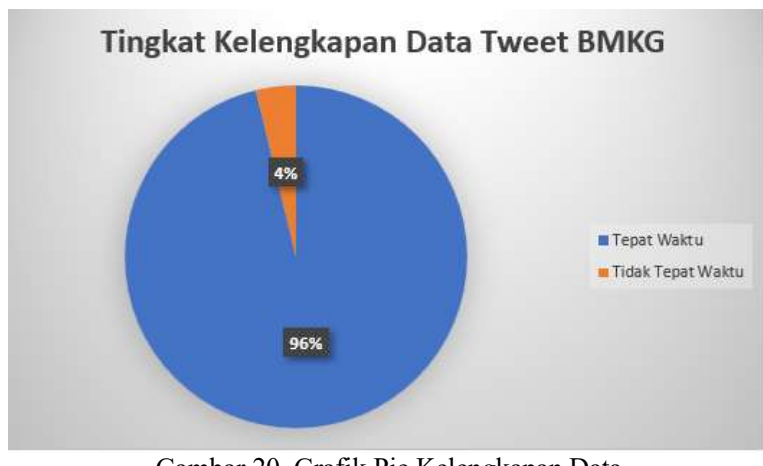

Gambar 20. Grafik Pie Kelengkapan Data

Gambar 19 menunjukkan hasil pengolahan data untuk tingkat ketepatan waktu Tweet informasi BMKG. Setelah data diolah didapatkan hasil persentase sebesar $80 \%$ untuk data yang tepat waktu dan $20 \%$ data yang tidak tepat waktu. Gambar 20 menunjukkan hasil pengolahan data untuk tingkat kelengkapan data Tweet informasi BMKG. Setelah data diolah didapatkan hasil persentase sebesar $96 \%$ untuk data yang lengkap dan $4 \%$ data yang tidak lengkap.

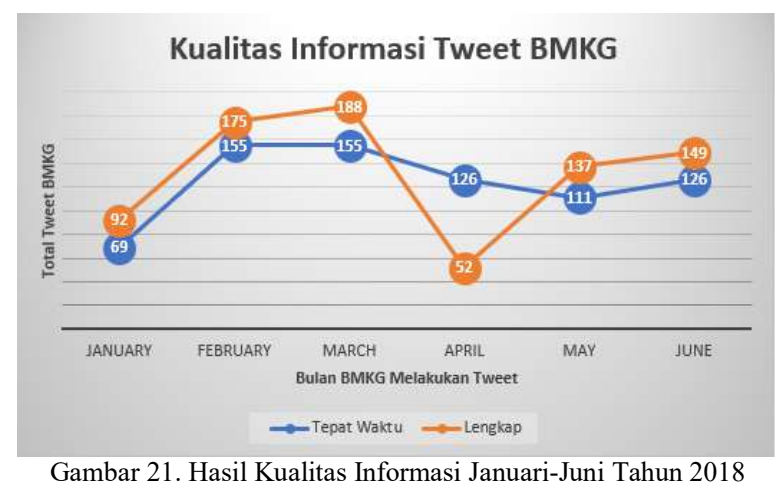

Gambar 21 menunjukkan hasil Kualitas Informasi dari Tweet BMKG di media sosial Twitter. Hasil menampilkan tingkat ketepatan waktu dan tingkat kelengkapan data yang ditampilkan dalam kurun waktu 6 bulan dari bulan Januari Hingga Juni di tahun 2018.

Hasil pengolahan data secara keseluruhan ditampilkan pada gambar 22. Didapatkan tingkat Kualitas Informasi dari Tweet informasi BMKG mengenai gempa bumi di Indonesia melalui media sosial Twitter, dengan hasil yang didapatkan adalah sebagai berikut:

1. Tingkat Akurasi $25 \%$

2. Tingkat Relevansi $25 \%$

3. Tingkat Ketepatan Waktu $20.01 \%$

4. Tingkat Kelengkapan Data $24.08 \%$

Sehingga data hasil Kualitas Informasi Tweet BMKG didapatkan sebesar $94.09 \%$ dan jika dibandingkan dengan tabel Kualitas Informasi, hasil yang didapatkan adalah Kualitas Informasi dari Tweet Informasi BMKG "Sangat Baik”.

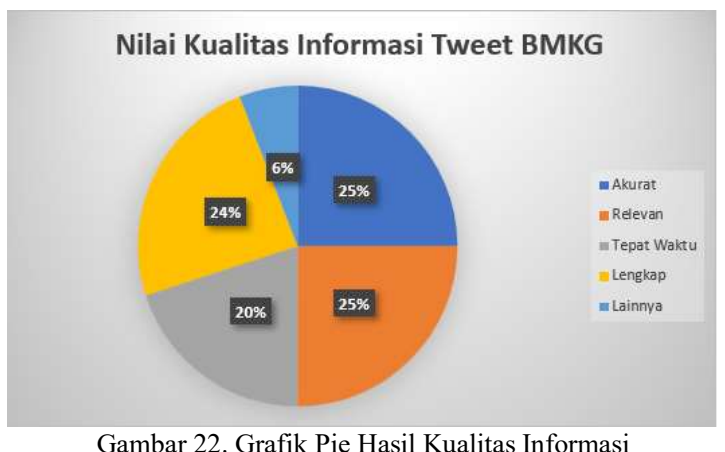

Gambar 22. Grafik Pie Hasil Kualitas Informasi 


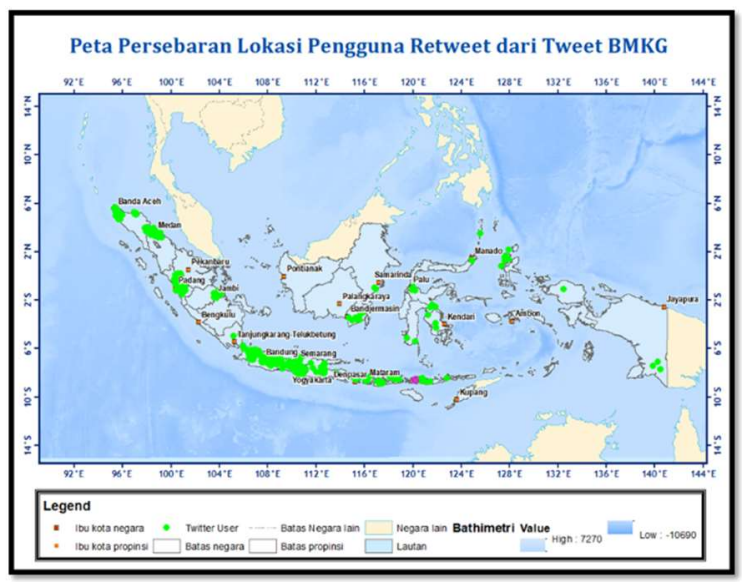

Gambar 23. Peta Persebaran Retweet Terhadap Tweet BMKG

Gambar 23 menunjukkan hasil visualisasi peta persebaran lokasi pengguna yang melakukan retweet terhadap tweet BMKG mengenai gempa bumi di Indonesia yang terjadi pada bulan Januari hingga Juni di tahun 2018. Simbol warna jingga menujukkan ibu kota negara dan ibu kota propinsi yang ada di Indonesia. Simbol warna hijau menunjukkan titik lokasi pengguna yang melakukan retweet terhadap tweet BMKG. Data didapatkan dari proses pengumpulan data lokasi pengguna yang melakukan retweet terhadap tweet $\mathrm{BMKG}$, setelah itu pemetaan peta persebaran dibuat berdasarkan data lokasi yang telah dikumpulkan.

\section{KESIMPULAN}

Berdasarkan hasil yang di dapatkan dari pengujian dan analisis hasil visualisasi maka dapat di simpulkan bahwa:

1. Kualitas penyebaran informasi gempa bumi di media sosial Twitter yang telah di lakukan BMKG selama 6 bulan terakhir dari bulan Januari hingga bulan Juni di tahun 2018 sudah "Baik" dan efektif dikarenakan hasil kualitas informasi yang didapatkan sebesar 94.09\%.

2. Kualitas penyebaran informasi menunjukkan bahwa:

- $\quad$ BMKG melakukan Tweet informasi gempa bumi BMKG di Twitter di bulan Januari hingga Juni tahun 2018 sebanyak 927 Tweet.

- Tweet dengan persentase ketepatan waktu informasi gempa bumi tertinggi yaitu sebanyak 155 Tweet terjadi di bulan Februari dan Maret.
- $\quad$ Tingkat dengan kelengkapan data tertinggi terjadi di bulan Maret dengan total Tweet sebanyak 188 Tweet.

3. Hasil pengolahan data dapat di visualisasikan dalam bentuk visualisasi grafik dan peta persebaran yang berisikan total Tweet informasi gempa dan hasil analisis kualitas informasi Tweet BMKG berserta lokasi pengguna yang melakukan retweet terhadap tweet BMKG mengenai gempa bumi selama 6 bulan dari bulan Januari hingga bulan Juni di tahun 2018.

\section{UCAPAN TERIMA KASIH}

Terimakasih kepada segenap Manajemen Politeknik Negeri Batam yang telah mendukung penulis dalam melakukan Riset ini.

\section{DAFTAR PUSTAKA}

[1] Pusdalops (2016) Ring of Fire. [Online]. Tersedia: http://bpbd.jabarprov.go.id/index.php/component/k2/item/38cincin-api- pasifik (diakses 8 Maret 2018)

[2] A. T. Chatfield and U. Brajawidagda, "Twitter early tsunami warning system: A case study in Indonesia's natural disaster management," in 2013 46th Hawaii International Conference on System Sciences, 2013, pp. 2050-2060.

[3] D. E. Kurniawan, and A. Fatulloh, "Clustering of Social Conditions in Batam, Indonesia Using K-Means Algorithm and Geographic Information System," International Journal of Earth Sciences and Engineering (IJEE) 2017, Vol.10 No.05

[4] R. Mareta, A. D. Rahmaningsih, and R. D. Firmansyah, "Pendeteksi Ketinggian Air Interaktif Dengan Aplikasi Telegram Berbasis Raspberry Pi," JST (Jurnal Sains dan Teknol., vol. 6, no. 2, pp. 279-289, 2017.. 2012

[5] E. M. G. Younis, "Sentiment analysis and text mining for social media microblogs using open source tools: an empirical study," Int. J. Comput. Appl., vol. 112, no. 5, 2015.

[6] B. W. Santoso, F. Sundawa, and M. Azhari, "Implementasi Algoritma Brute Force Sebagai Mesin Pencari (Search Engine) Berbasis Web Pada Database," J. Sisfotek Glob., vol. 6, no. 1, 2016.

[7] J. O'brien and G. Marakas, Introduction to information systems McGraw-Hill, Inc., 2009.

[8] R. McLeod and G. Schell, Sistem informasi manajemen. Indeks, 2004. Terjemahan oleh Ali Akbar Yulianto dan Afia R. Fitriati, Salemba Empat, Jakarta 2008 